Article

\title{
Ionic Liquid Composite Polybenzimidazol Membranes for High Temperature PEMFC Applications
}

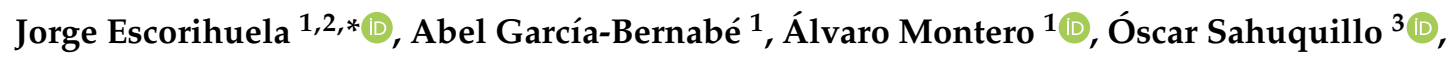 \\ Enrique Giménez ${ }^{3}$ and Vicente Compañ ${ }^{1, * \mathbb{D}}$ \\ 1 Departamento de Termodinámica Aplicada, (ETSII) Universitat Politècnica de València, Camino de Vera s/n, \\ 46022 Valencia, Spain; agarciab@ter.upv.es (A.G.-B.); almonter@upvnet.upv.es (Á.M.) \\ 2 Departament de Química Orgànica, Universitat de València, Av. Vicent Andrés Estellés s/n, \\ 46100 Burjassot, Valencia, Spain \\ 3 Instituto de Tecnología de Materiales, Universitat Politècnica de València, Camino de Vera s/n, \\ 46022 Valencia, Spain; ossana@upvnet.upv.es (Ó.S.); enrique.gimenez@mcm.upv.es (E.G.) \\ * Correspondence: escorihu@uji.es (J.E.); vicommo@ter.upv.es (V.C.); Tel.: +34-96-387-9328 (V.C.)
}

Received: 9 April 2019; Accepted: 18 April 2019; Published: 22 April 2019

check for updates

\begin{abstract}
A series of proton exchange membranes based on polybenzimidazole (PBI) were prepared using the low cost ionic liquids (ILs) derived from 1-butyl-3-methylimidazolium (BMIM) bearing different anions as conductive fillers in the polymeric matrix with the aim of enhancing the proton conductivity of PBI membranes. The composite membranes prepared by casting method (containing 5 wt. \% of IL) exhibited good thermal, dimensional, mechanical, and oxidative stability for fuel cell applications. The effects of anion, temperature on the proton conductivity of phosphoric acid-doped membranes were systematically investigated by electrochemical impedance spectroscopy. The PBI composite membranes containing 1-butyl-3-methylimidazolium-derived ionic liquids exhibited high proton conductivity of $0.098 \mathrm{~S} \cdot \mathrm{cm}^{-1}$ at $120{ }^{\circ} \mathrm{C}$ when tetrafluoroborate anion was present in the polymeric matrix. This conductivity enhancement might be attributed to the formed hydrogen-bond networks between the IL molecules and the phosphoric acid molecules distributed along the polymeric matrix.
\end{abstract}

Keywords: fuel cells; materials science; proton exchange membrane; polymer; polybenzimidazole; ionic liquid; proton conductivity; electrochemical impedance spectroscopy

\section{Introduction}

In the last decades, the scientific community is more concerned about the environmental impact caused by the use of fossil fuels as an energy source. In this scenario, fuel cells have emerged as a new kind of energy transformation device and have been considered as a sustainable and environmentally friendly energy conversion procedure [1]. Among the different variety of fuel cell types, proton exchange membrane fuel cells (commonly referred to as polymer electrolyte membrane fuel cells, PEMFCs) are electrochemical devices that convert chemical energy from a fuel and oxygen into electrical energy, and they have recently attracted increasing interest from fundamental and an applied science due to their future potential as clean and portable power sources [2-5]. In a typical PEMFC, the polymer electrolyte membrane (PEM) constitutes the fundamental part of the fuel cell technology as it is responsible for the necessary ions conduction between the anode and cathode [6]. Among the different PEMs, perfluorosulfonate acid (PFSA) membranes have received much attention along the last decades because they provide high power density at operating temperatures below $80{ }^{\circ} \mathrm{C}$ [7], and particularly Nafion has been the most widely used ionomer for electrochemical applications [8]. 
Although Nafion currently dominates the fuel cell market, reaching proton conductivities in the range of $0.1 \mathrm{~S} \cdot \mathrm{cm}^{-1}$ [9], the serious drawbacks, such as temperature effects on the mechanical properties [10] and the proton conductivity decrease at temperatures over $80^{\circ} \mathrm{C}$, have driven efforts for the quest for new polymer electrolytes, which are capable of operating at high temperatures $\left(>100^{\circ} \mathrm{C}\right)$ with high conductivity values under low or anhydrous conditions [11,12].

Energy applications in general, and in particular the automotive industry, need effective polymer electrolyte membranes capable of working at higher temperatures (in the window of $120-140{ }^{\circ} \mathrm{C}$ ); PEMFCs working within this temperature range are called high temperature proton exchange membrane fuel cells (HT-PEMFCs) [13-16]. HT-PEMFCs offer several advantages over PEMFCs working at lower temperatures, such as simple heat and water management and high tolerance of $\mathrm{CO}$ in the fuel [17]. In this context, it is known that a fuel cell operating pressure of 1.5 bar leads to the requirement of fuel cell components that can operate with $25 \%$ relative humidity $(\mathrm{RH})$ at $120{ }^{\circ} \mathrm{C}$ because only a 0.5 bar water vapor partial pressure is tolerated [18]. In the quest for developing low cost PEMs with high conductivity at moderate and elevated temperatures, the use of non-perfluorinated polymers has emerged as an alternative to Nafion membranes [19]. In this regard, the main difficulty is to develop PEMs with high proton conductivity, high chemical stability, and high mechanical strength at high temperatures. Among all non-perfluorinated membranes, polybenzimidazole (PBI) has emerged as an attractive candidate to replace Nafion membranes due to its superior thermal and mechanical stability [20]. PBI membranes exhibit low proton conductivities under low humidity conditions. However, they can be significantly improved when doped with phosphoric acid (PA), showing conductivities up to $0.08 \mathrm{~S} \cdot \mathrm{cm}^{-1}$ at $150^{\circ} \mathrm{C}$, which is as high as a wetted Nafion membrane [21]. Although phosphoric acid doping enhances proton conductivity, its use has some drawbacks regarding acid leaking and phosphoric acid degradation over $160^{\circ} \mathrm{C}$, resulting in a decrease of proton conductivity. As a consequence, significant efforts have been focused on the search for new approaches to enhance PBI conductivity. In the last years, different approaches were developed in order to overcome this problem and improve the mechanical/dimensional properties and proton conductivity performance of PBI membranes at elevated temperatures by using several fillers such as silica and clay [22,23], metalcarborane and metal oxides [24], phosphate salts [25], heteropolyacids [26], metal organic frameworks (MOFs) [27,28], graphene oxide (GO), [29,30] and more recently, ionic liquids [31,32].

Ionic liquids (ILs) are molten salts composed of organic cations and inorganic anions with low melting points around room temperature (below $100^{\circ} \mathrm{C}$ ) [33,34]. ILs are promising compounds for the preparation of electrochemical devices because they exhibit high thermal stability, good conductivities and low or even neglected leaching of the bulk IL component has been detected when the ILs is taking part in a polymeric matrix [35,36]. In recent years, the use of ILs as fillers in polymer-based membranes has been deeply studied in gas separation processes [37], drug sensing [38], pharmaceutics and medicine [39], transport agents [40], catalysis [41-43], and energy storage and conversion [44-46]. ILs offer a significant advantage over phosphoric acid doping as they are highly stable at temperatures higher than $160^{\circ} \mathrm{C}$. One of the biggest advantages of ILs is their potential application as a filler of novel polymeric membranes that combines the good properties of the ILs with those of polymers to build composite polyelectrolytes as polymer ionic liquids (PILs) [47].

Herein, in this work we have prepared different proton conducting PBI composite membranes by incorporating 1-butyl-3-methylimidazolium (BMIM)-derived IL bearing different anionic units ([Cl] ${ }^{-}$, $[\mathrm{Br}]^{-},[\mathrm{I}]^{-},[\mathrm{NCS}]^{-},\left[\mathrm{NTf}_{2}\right]^{-},\left[\mathrm{PF}_{6}\right]^{-}$and $\left.\left[\mathrm{BF}_{4}\right]^{-}\right)$in the polymeric network. Composite membranes with different anions were prepared by solution casting and the structure, morphology, thermal stability, mechanical strength, oxidative resistance and proton conductivity of these prepared materials were analyzed to study their sustainability to be used as HT-PEMFCs. The incorporation of ionic liquids as fillers in PBI membranes improves the proton conductivity, with values up to $94 \mathrm{mS} \cdot \mathrm{cm}^{-1}$ being obtained for the corresponding composite membrane containing BMIM-BF4 at $200{ }^{\circ} \mathrm{C}$ under anhydrous conditions. 


\section{Materials and Methods}

\subsection{Materials.}

PBI (purity > 99.95\%, MW 51000, with the molecular formula: $\left.\left(\mathrm{C}_{20} \mathrm{H}_{12} \mathrm{~N}_{4}\right)_{n}\right)$ was purchased from Danish Power Systems (Danish Power Systems, Kvistgaard, Denmark). $\mathrm{LiCl}, \mathrm{N}, \mathrm{N}$-dimethylacetamide (DMAc) 99.8\%, 1-butyl-3-methylimidazolium chloride (BMIM-Cl), 1-butyl-3-methylimidazolium bromide (BMIM-Br), 1-butyl-3-methylimidazolium iodide (BMIM-I),

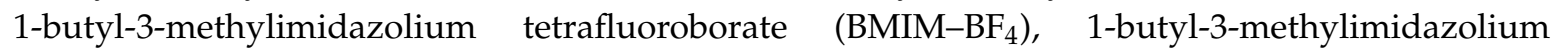
hexafluorophosphate $\left(\mathrm{BMIM}^{-} \mathrm{PF}_{6}\right)$, 1-butyl-3-methylimidazolium bis(trifluoromethylsulfonyl)imide (BMIM-NTf $_{2}$, and 1-butyl-3-methylimidazolium thiocyanate (BMIM-NCS) were purchased from Sigma-Aldrich (Sigma-Aldrich Química SL, Madrid, Spain). N,N-Dimethylacetamide (DMAc, 99.5\% extra pure) and phosphoric acid (extra pure, $85 \%$ solution in water) were purchased from Acros Organics (Fisher Scientific SL, Madrid, Spain).

\subsection{Characterization}

Scanning electron microscopy (SEM) images were acquired on a field emission scanning electron microscope (FE-SEM) model Ultra 55 (Zeiss, Oberkochen, Germany) operating at $5 \mathrm{kV}$ with energy-dispersive X-ray (EDX) spectroscopy. Electron micrographs were obtained using a Jeol JEM-1010 high resolution microscope (JEOL Ltd., Garden City, UK). Attenuated total reflection Fourier transform infrared (ATR-FTIR) spectra of the membranes were recorded on a Jasco FT-IR spectrometer FT/IR-6200 Series (Jasco Spain, Madrid, Spain) with a $4 \mathrm{~cm}^{-1}$ resolution between 400 and $4000 \mathrm{~cm}^{-1}$. Thermogravimetric analysis (TGA) was performed on a TGA Q50 thermogravimetric analyzer TGA Q50 (Waters Cromatografia, S.A., Division TA Instruments, Cerdanyola del Valles, Spain). The samples (5-10 $\mathrm{mg}$ ) were weighed in platinum crucibles and were heated under nitrogen atmosphere $\left(60 \mathrm{~mL} \cdot \mathrm{min}^{-1}\right)$ from room temperature to $800{ }^{\circ} \mathrm{C}$ at a heating rate of $10{ }^{\circ} \mathrm{C} \cdot \mathrm{min}^{-1}$. For the surface area and porosity analysis, the solid or membrane was dried in a vacuum oven at $100^{\circ} \mathrm{C}$ for $5 \mathrm{~h}$ and activated at $100^{\circ} \mathrm{C}$ for $12 \mathrm{~h}$ on a SmartVacPrep instrument (Micromeritics Instrument Corporation, Norcross, GA, USA). The acid uptake (AU) of the membrane was calculated by the following equation: $\mathrm{AU}(\%)=\left[\left(W_{\text {wet }}-W_{\text {dry }}\right) / W_{\text {dry }}\right] \times 100$; where $W_{\text {wet }}$ and $W_{\text {dry }}$ refer to the membrane's weight after its immersion in phosphoric acid for at least $48 \mathrm{~h}$ at room temperature and the membrane's weight after drying at $120^{\circ} \mathrm{C}$ for at least $24 \mathrm{~h}$, respectively. The oxidative stability (OS) of the membranes was investigated by immersing the membranes in Fenton's reagent $\left(3 \% \mathrm{H}_{2} \mathrm{O}_{2}\right.$ solution containing $4 \mathrm{ppm}$ $\mathrm{Fe}^{2+}$ ) at $70{ }^{\circ} \mathrm{C}$. The samples were collected by filtering and rinsing with deionized water several times, then dried at $120^{\circ} \mathrm{C}$ for $5 \mathrm{~h}$ in a vacuum oven. Next, the degradation of the membranes was evaluated by their weight loss by using the following equation: OS $(\%)=\left[\left(W_{1}-W_{2}\right) / W_{1}\right] \times 100$; where $W_{1}$ is the weight of the dried membrane before the Fenton test and $W_{2}$ is the weight of the dried membrane after the Fenton test. The tensile properties of the membranes were determined from stress-strain curves obtained with a universal testing machine (Shimadzu AGS-X) at a crosshead rate of $10 \mathrm{~mm} \cdot \mathrm{min}^{-1}$ at room temperature. The membranes were cut into strips of $30 \mathrm{~mm} \times 6 \mathrm{~mm}$ and were around $100 \mu \mathrm{m}$ thick. Five specimens of each sample were tested and the average results with standard deviation were reported. The proton conductivity measurements of the membranes in the transversal direction were performed in the temperature range between 0 and $200^{\circ} \mathrm{C}$ by electrochemical impedance spectroscopy (EIS) in the frequency interval of $0.1 \mathrm{~Hz}$ to $10 \mathrm{MHz}$, applying a $0.1 \mathrm{~V}$ signal amplitude. A broadband dielectric spectrometer (Novocontrol Technologies, Hundsangen, Germany) integrated with an SR 830 lock-in amplifier with an Alpha dielectric interface was used. The membranes were previously immersed in deionized water and the thickness was measured afterwards using a digital micrometer, taking the average measurements at different parts of the surface. Then, the membranes were placed between two gold electrodes coupled to the spectrometer. Initially, the temperature was gradually raised from 20 to $120^{\circ} \mathrm{C}$ in steps of $10^{\circ} \mathrm{C}$ and the dielectric spectra were collected at each step. During the second cycle of temperature scan (named as anhydrous conditions), the dielectric spectra were 
collected at each step. In addition, during the second cycle of the temperature scan (called as dry conditions in the manuscript), the dielectric spectra were collected at each step from 0 to $200{ }^{\circ} \mathrm{C}$, in steps of $10^{\circ} \mathrm{C}$.

\subsection{Experimental Procedures}

\subsubsection{Preparation of the PBI Solution}

$\mathrm{LiCl}(0.1 \mathrm{wt}$. \%) was used as a stabilizer and was dissolved in DMAc with vigorous stirring ( $1 \mathrm{~h}$ at room temperature) to give a homogeneous solution. Next, PBI powder (10 wt. \%) was dissolved in the $\mathrm{LiCl}$ solution (in DMAc) and heated under reflux at $120^{\circ} \mathrm{C}$ for $6 \mathrm{~h}$. The prepared solution had a viscosity of $0.5 \mathrm{~Pa} \cdot \mathrm{s}$ at $25^{\circ} \mathrm{C}$.

\subsubsection{Membrane Preparation}

The amount of $0.025 \mathrm{~g}$ of ionic liquid was totally dissolved in $4.975 \mathrm{~g}$ of the $10 \mathrm{wt}$. \% PBI solution and placed in an ultrasonic bath for $20 \mathrm{~min}$ to give a final solution with a $5 \mathrm{wt}$. \% of IL with respect to PBI. Next, the homogeneous solution was stirred for $4 \mathrm{~h}$ at $60^{\circ} \mathrm{C}$. Then, the solution was cast onto a glass slide and dried at $70^{\circ} \mathrm{C}$ for $10 \mathrm{~h}$, then at $140{ }^{\circ} \mathrm{C}$ for $10 \mathrm{~h}$, and finally at $120^{\circ} \mathrm{C}$ under vacuum overnight. Membranes were washed with distilled water at $80^{\circ} \mathrm{C}$ in order to remove residual solvent (DMAc). Traces of the solvent were finally removed by drying at $160^{\circ} \mathrm{C}$ for $16 \mathrm{~h}$. The membrane thicknesses prior to acid doping varied between 190 and $210 \mu \mathrm{m}$.

\section{Results and discussion}

Composite PBI membranes containing ILs were prepared by casting method (Figure 1). For this purpose, the amount of ionic liquid $(0.05 \mathrm{~g})$ was dissolved in the $10 \mathrm{wt}$. \% PBI solution $(10 \mathrm{~g})$ under vigorous stirring to give the PBI solution containing $5 \mathrm{wt}$. \% of ionic liquid. This solution was cast onto a glass plate and dried at $80^{\circ} \mathrm{C}$ for $8 \mathrm{~h}$; then is was dried at $160^{\circ} \mathrm{C}$ for $10 \mathrm{~h}$. Then, membranes were peeled of the glass plate and finally dried under pressure at $140^{\circ} \mathrm{C}$ for $10 \mathrm{~min}$. Membranes were washed with distilled water at $80^{\circ} \mathrm{C}$ in order to remove residual solvent (DMAc). Traces of the solvent were removed by drying at $160^{\circ} \mathrm{C}$ for $16 \mathrm{~h}$. The membrane thicknesses prior to acid doping varied between 190 and $210 \mu \mathrm{m}$.

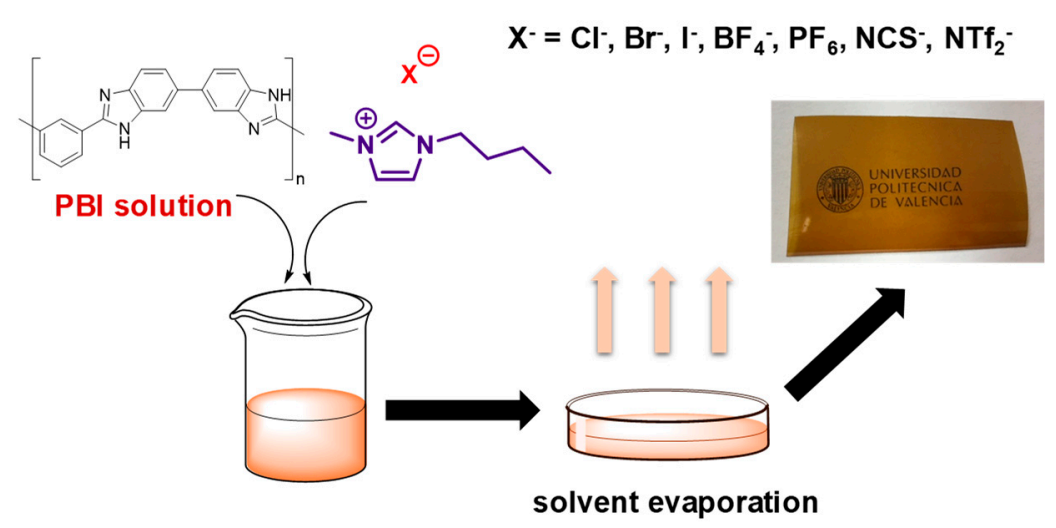

Figure 1. Schematic representation of PBI composite membranes containing ionic liquids and photograph of PBI@BMIM-NTf 2 membrane.

Infrared spectroscopy is highly useful for studies on materials science. Figure 2 shows the FT-IR spectra of the $5 \mathrm{wt}$. \% IL-PBI composite membranes in the range of $4000-600 \mathrm{~cm}^{-1}$. The pure PBI membrane showed a typical broad peak around $3500-3200 \mathrm{~cm}^{-1}$ attributed to the $\mathrm{N}-\mathrm{H}$ stretching, and two bands at 1610 and $1423 \mathrm{~cm}^{-1}$, which are associated with $\mathrm{C}=\mathrm{N}$ and $\mathrm{C}-\mathrm{N}$ stretching vibrations, respectively [48]. After incorporation of the IL in the polymer matrix, the presence 
of 1-butyl-3-methylimidazolium bis(trifluoromethylsulfonyl)imide in the membranes was confirmed by the presence of peaks at $1192 \mathrm{~cm}^{-1}\left(\mathrm{CF}_{3}\right.$ stretching), $1591 \mathrm{~cm}^{-1}\left(\mathrm{SO}_{2}\right.$ asymmetric stretching), $1131 \mathrm{~cm}^{-1}\left(\mathrm{SO}_{2}\right.$ symmetric stretching), and $1052 \mathrm{~cm}^{-1}$ (S-N stretching) [49]. For the PBI membrane containing $5 \mathrm{wt}$. \% BMIM-NCS, a characteristic band from the thiocyanate group was observed at $2058 \mathrm{~cm}^{-1}$. A shift of IR peak at $1608 \mathrm{~cm}^{-1}$ to a higher wavenumber was observed for some ILs under study, attributed to the presence of hydrogen bond interactions between IL and the polymeric matrix [50].

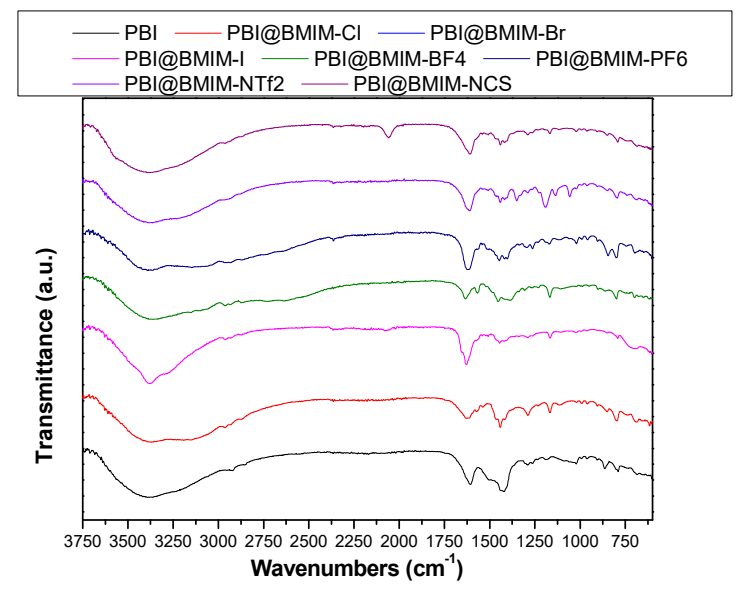

Figure 2. FT-IR spectra of PBI and PBI composite membranes containing different ionic liquids derived from BMIM (5 wt. \%).

The internal microscopic morphologies of membranes were studied by SEM. The cryofractured cross sections of the different PBI composite membranes containing $5 \mathrm{wt}$. \% of ionic liquid are shown in Figure 3. The surface of the PBI membranes was dense and free of holes. However, the addition of ILs as fillers was reflected in the appearance of holes in the cross section SEM images. After PA doping, the morphology of all membranes showed the formation of channels due to the presence of PA in the polymer network, as observed in similar systems [51]. After immersion in $\mathrm{H}_{3} \mathrm{PO}_{4}$ aqueous solution $(15 \mathrm{M})$, acid uptake (AU) was calculated from weight difference and values around $243 \%-256 \%$ were obtained for composite membranes containing $5 \mathrm{wt}$. \% of ionic liquid. It is worth mentioning that the prepared polymeric membranes are stable and no coloration was observed even in $15 \mathrm{M} \mathrm{H}_{3} \mathrm{PO}_{4}$.
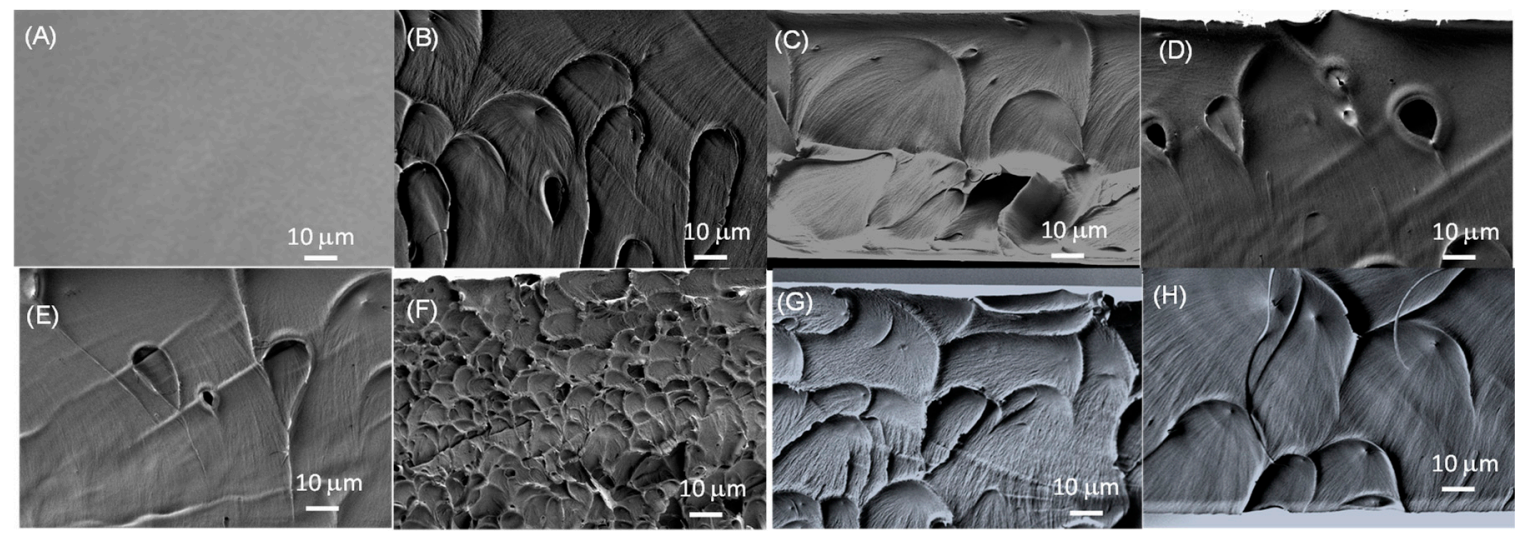

Figure 3. Cross-sectional SEM images of (A) PBI, (B) PBI@BMIM-Cl, (C) PBI@BMIM-Br, (D) PBI@BMIM-I, (E) PBI@BMIM-NCS, (F) PBI@BMIM-BF,

High stability at elevated temperatures is one of the requirements that ideal polymer electrolyte membranes must fulfil in order to guarantee proton transport. The thermal properties of undoped PBI-based membranes containing ionic liquids derived from BMIM (5 wt. \%) with different anions 
were studied by TGA under a $\mathrm{N}_{2}$ atmosphere (Figure $4 \mathrm{a}$ ). For the pure PBI membrane, about $5 \%$ loss occurred in the range of temperature from 50 to $250{ }^{\circ} \mathrm{C}$, which is attributed to the dehydration of absorbed water molecules and traces of DMAc. Finally, polymeric backbone degradation occurs around $710{ }^{\circ} \mathrm{C}$. All PBI composite membranes containing $5 \mathrm{wt}$. \% of ionic liquid showed high thermal stability up to $200{ }^{\circ} \mathrm{C}$, with a with a weight loss of $3 \%-8 \%$ depending on the anion of BMIM. In the $250-500{ }^{\circ} \mathrm{C}$ range of decomposition temperatures also occurs the thermal degradation of ionic liquids incorporated into the PBI membranes, as decomposition of BMIM anion occurred in the range $350-500{ }^{\circ} \mathrm{C}$ [52]. This decomposition is partially masked with primary polymer degradation. The degradation step observed at about $600{ }^{\circ} \mathrm{C}$ was associated with the degradation of the PBI main chain [53]. After several decomposition stages, composite membranes remained with $70 \%-76 \%$ weight at $800{ }^{\circ} \mathrm{C}$, slightly lower than pure PBI membrane (79\% weight). Comparing with the undoped membranes, the weight loss curves for the PA-doped membranes showed a similar degradation trend (Figure $4 \mathrm{~b}$ ). The first weight loss step was observed at $160-165^{\circ} \mathrm{C}$ due to the PA dehydration and the subsequent formation of pyrophosphoric acid $\left(\mathrm{H}_{4} \mathrm{P}_{2} \mathrm{O}_{7}\right)[54,55]$ and more complex phosphate species at higher temperature, as previously reported in similar PA-doped PBI membranes [56-58]. The $\mathrm{T}_{\mathrm{d}, 95}$ (where the weight loss reaches 5 wt. \%) of PBI composite membranes was around $300-350{ }^{\circ} \mathrm{C}$. After PA doping, a thermal stability reduction was observed compared to undoped membranes, as shown by the $T_{\mathrm{d}, 95}$, which was lowered to $180-210^{\circ} \mathrm{C}$ for doped membranes, which results from the PA dehydration and formation of pyrophosphoric acid or other phosphate species. From the results, it can be concluded that the composite membranes reported in this study possess enough thermal stability for its application as high temperature proton exchange membrane fuel cells.

(a)

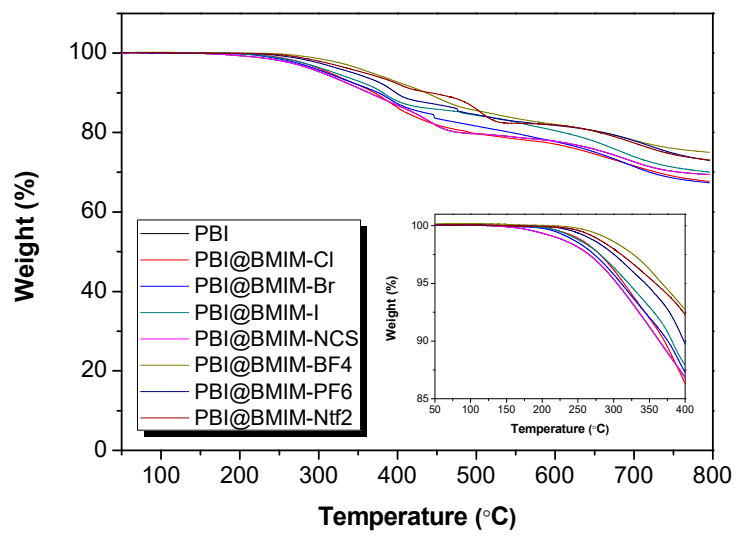

(b)

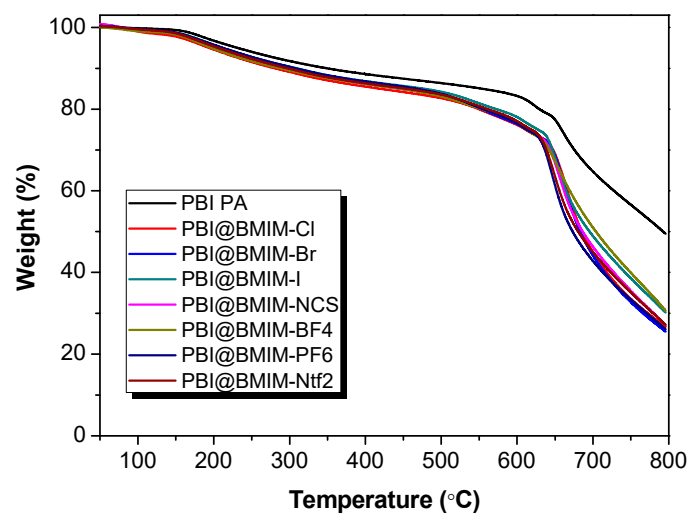

Figure 4. TGA curves of (a) undoped and (b) phosphoric acid-doped PBI composite membranes containing different ionic liquids derived from BMIM (5 wt. \%) under a $\mathrm{N}_{2}$ atmosphere.

During the operation of PEMFCs, the polymeric membrane can be degraded by radicals; therefore, the evaluation of stability is a necessary test when developing novel PEMs. In this work, the oxidative stability of the composite membranes containing $5 \mathrm{wt}$ \% of IL was evaluated by weight loss in relation to the initial weight after immersion in the Fenton's solution [59]. The pure PBI membrane showed a weight decrease around $20 \%$ after $24 \mathrm{~h}$ and $40 \%$ after $196 \mathrm{~h}$ ( 1 week). In contrast, the weight decrease of all composite membranes was below 15 and $30 \%$ after 24 and $196 \mathrm{~h}$, respectively (Figure 5). The addition of the IL enables a crosslinking network, which improves the stability of the composite membranes as already observed for other blend membranes. The oxidative stabilities of composite membranes are in the same range as those reported for other non-fluorinated analogs in literature [60].

The mechanical properties of the undoped PBI composite membranes containing $5 \mathrm{wt}$. \% of BMIM-X were evaluated by tensile testing. A summary of the tensile testing results is shown in Table 1 . In all cases, the Young's modulus and tensile strength of the composite membranes increased with the addition of the ionic liquid ( $5 \mathrm{wt}$. \%) as filler, indicating that the ILs can improve the mechanical 
properties of PBI by an interaction between the polymer matrix and the absorbed ILs. It should be noted that the composite with BMIM-Cl showed a significant increase in the values of Young's modulus and tensile strength with respect to pure PBI (2.6 GPa and $97 \mathrm{MPa}$, respectively), up to 2.8-3.7 GPa and 124-141 MPa, respectively. However, the strain at break decreases with IL loading, indicating a higher brittle in the composite membranes than in the PBI alone. Moreover, the membrane PBI-BMIM-NTF 2 showed a good balance of mechanical properties, by offering high strength and a lower decrease in strain at break compared with the other composite membranes studied [61]. After the acid doping, the stress-strain curves for these composite materials exhibited a rubbery nature (a decrease in tensile strength and Young's modulus but an increase in the strain at break was observed), due to the uptake of $\mathrm{H}_{3} \mathrm{PO}_{4}$; contrarily to shows that exhibited a glassy nature all the undoped membranes [62].

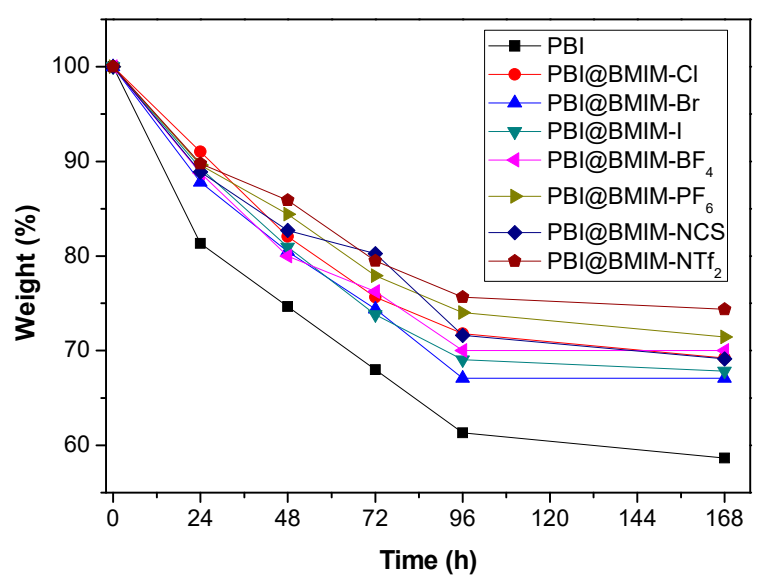

Figure 5. Weight loss of the IL composite membranes (containing $5 \mathrm{wt}$ \% of BMIM-X) and PBI after Fenton test.

Table 1. Mechanical properties of undoped IL composite PBI membranes (containing 5 wt. \% of BMIM-X) studied in this work.

\begin{tabular}{cccc}
\hline Membrane & Young's Modulus (GPa) & Tensile Stress (MPa) & Strain at break (\%) \\
\hline PBI & $2.6 \pm 0.5$ & $97 \pm 4$ & $27 \pm 4$ \\
PBI@BMIM-Cl & $3.7 \pm 0.1$ & $141 \pm 3$ & $9 \pm 1$ \\
PBI@BMIM-Br & $3.0 \pm 0.3$ & $128 \pm 4$ & $15 \pm 3$ \\
PBI@BMIM-I & $3.6 \pm 0.1$ & $131 \pm 3$ & $7 \pm 1$ \\
PBI@BMIM-BF4 & $2.8 \pm 0.1$ & $125 \pm 4$ & $17 \pm 4$ \\
PBI@BMIM-PF6 & $3.4 \pm 0.3$ & $124 \pm 2$ & $8 \pm 1$ \\
PBI@BMIM-NCS & $3.6 \pm 0.4$ & $131 \pm 3$ & $10 \pm 1$ \\
PBI@BMIM-NTf & $3.1 \pm 0.3$ & $127 \pm 2$ & $19 \pm 1$ \\
\hline
\end{tabular}

Proton conductivity of composite membranes was evaluated by electrochemical impedance spectroscopy (EIS). In the last decades, this electrochemical technique has been applied to measure the through-plane conductivity of PEMs [63,64]. The proton transport was determined by investigating the dependence of proton conductivity on the temperature under anhydrous conditions from 0 to $200{ }^{\circ} \mathrm{C}$ (see Supplementary Information, Table S1). The dc-conductivity for the composite membranes was obtained by means of the Bode diagram $[65,66]$. In this graphical representation for PBI@BMIM-NTf 2 (see Figure 6), the modulus of the complex impedance $\left|\sigma^{*}\right|$ is plotted against the frequency $\omega$ (i.e., $\left|Z^{*}\right|$ vs. $\omega$ ). In a typical Bode diagram, as frequency increases, the modulus increases, reaching a plateau at a given frequency ( $\sigma^{\prime}$ is constant with the frequency), whereas the out of phase angle $\phi=\tan ^{-1}\left(Z^{\prime \prime} / Z^{\prime}\right)$ reaches a maximum (or generally tends to zero). Since $\lim \left|Z^{*}\right| \rightarrow R_{0}$ and $\phi=0$ at $\omega \rightarrow \infty$, the ionic resistance is $R_{0}=\left|Z^{*}\right|$ at $\tan ^{-1}\left(Z^{\prime \prime} \mid Z^{\prime}\right)=0$, and then the dc-conductivity is the constant value obtained from the plateau. The dc-conductivity $\left(\sigma_{\mathrm{dc}}, \mathrm{S} \cdot \mathrm{cm}^{-1}\right)$ is related with the impedance of the 
membrane by means of $\left(\sigma_{\mathrm{dc}}=\mathrm{L} /\left(\mathrm{R}_{0} \cdot \mathrm{S}\right)\right.$, where $\mathrm{L}(\mathrm{cm})$ is the thickness of the membrane, $\mathrm{A}\left(\mathrm{cm}^{2}\right)$ is the contact surface area between the electrodes and the membrane, and $R_{0}(\Omega)$ is the membrane resistance.
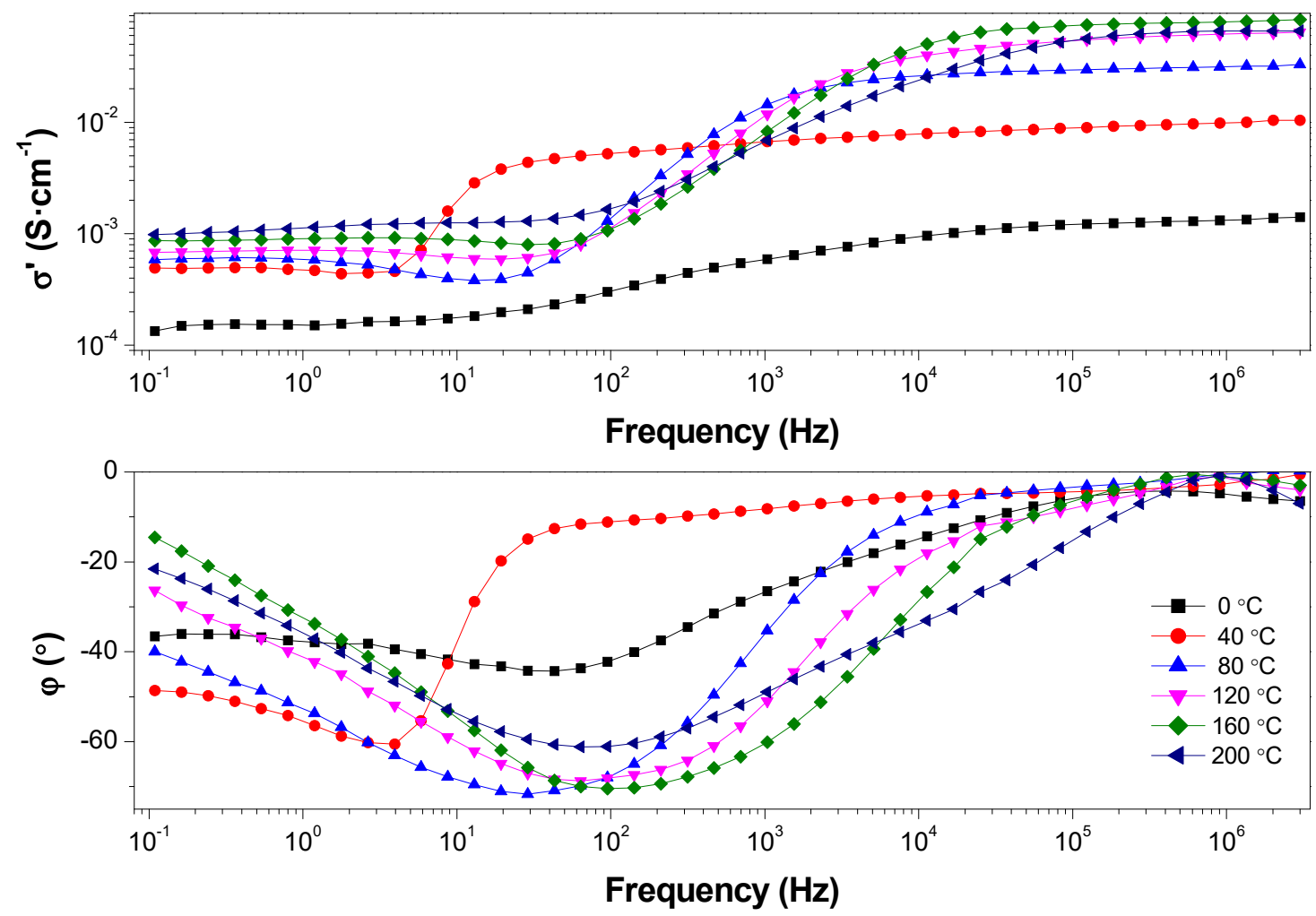

Figure 6. Bode diagram for phosphoric acid-doped PBI@BMIM-NTf 2 composite membrane (containing $5 \mathrm{wt}$. \% of BMIM-NTf 2 ) under anhydrous conditions. In the top graphical representation, $\sigma^{\prime}$ is plotted against the frequency, whereas in the bottom, the out of phase angle $\phi$ is plotted against the frequency.

As can be seen in Figure 6, the through-plane conductivities increased with temperature for the composite membranes, showing a linear temperature dependence between 0 and $100{ }^{\circ} \mathrm{C}$. In some cases, a decrease in conductivity was observed for temperatures over $160{ }^{\circ} \mathrm{C}$ due to the evaporation of phosphoric acid. As shown, proton conductivity showed a strong dependence on the anion present in the IL of the composite membrane. As an example (see Table 2), BMIM membranes containing halogen anions $(\mathrm{Cl}, \mathrm{Br}$ or I) displayed lower conductivity values than pristine $\mathrm{PBI}$ membrane at temperatures below $80^{\circ} \mathrm{C}$, with conductivities at $200{ }^{\circ} \mathrm{C}$ of 26,58 and $7 \mathrm{mS} \cdot \mathrm{cm}^{-1}$, for PBI@BMIM-Cl, PBI@BMIM-Br and PBI@BMIM-I, respectively. Composite membranes PBI@BMIM-PF 6 and PBI@BMIM-NCS showed similar conductivities, reaching maximum values of 23 and $26 \mathrm{mS} \cdot \mathrm{cm}^{-1}$ at $200{ }^{\circ} \mathrm{C}$, respectively. When comparing composite membranes PBI@BMIM-BF 4 and $\mathrm{PBI} @ B M I M-\mathrm{PF}_{6}$, the dc-conductivity for the former membrane was around four-fold higher over the whole temperature range, which might be attributed to the higher hydrophobicity of ionic liquid containing $\left[\mathrm{PF}_{6}\right]^{-}$anion, as hydrophobicity is dependent on the number of $\mathrm{F}$ atoms. Membranes containing anions such as $\left[\mathrm{NTf}_{2}\right]^{-}$and $\left[\mathrm{BF}_{4}\right]^{-}$ displayed the highest conductivities with values at $200{ }^{\circ} \mathrm{C}$ of 65 and $94 \mathrm{mS} \cdot \mathrm{cm}^{-1}$, for PBI@BMIM-NTf and PBI@BMIM-BF 4 , respectively. The influence of the anion on ionic liquid over the conductivity of the composite membranes can be interpreted in terms of the changes in polarity and hygroscopicity associated to the anion [67]. These values are similar to other reported PBI composite membranes containing ionic liquids under anhydrous conditions [68]. Although the experimental procedure was designed in order to eliminate the adsorbed water on the composite membranes by performing a previous cycle from 20 to $120^{\circ} \mathrm{C}$ before each measurement, this effect cannot be completely ruled out, as traces of water molecules can be retained in the polymeric matrix due to strong associations with the ionic liquids incorporated in the polymer. 
Table 2. Conductivity values (in S. $\mathrm{cm}^{-1}$ ) for some temperatures obtained from the Bode diagram for all phosphoric acid-doped PBI composite membranes containing 5 wt. \% of BMIM-X under anhydrous conditions.

\begin{tabular}{ccccccccc}
\hline $\mathbf{T}\left({ }^{\circ} \mathbf{C}\right)$ & $\mathbf{P B I}$ & {$[\mathbf{C l}]^{-}$} & {$[\mathbf{B r}]^{-}$} & {$[\mathbf{I}]^{-}$} & {$\left[\mathbf{B F}_{4}\right]^{-}$} & {$\left[\mathbf{P F}_{\mathbf{6}}\right]^{-}$} & {$\left[\mathbf{N C S}^{-}\right.$} & $\left.\mathbf{N T f}_{\mathbf{2}}\right]^{-}$ \\
\hline 0 & $1.2 \times 10^{-3}$ & $1.2 \times 10^{-5}$ & $1.9 \times 10^{-3}$ & $1.2 \times 10^{-4}$ & $8.5 \times 10^{-3}$ & $1.6 \times 10^{-3}$ & $2.6 \times 10^{-3}$ & $1.3 \times 10^{-3}$ \\
40 & $5.2 \times 10^{-3}$ & $4.8 \times 10^{-4}$ & $9.1 \times 10^{-3}$ & $7.9 \times 10^{-4}$ & $2.9 \times 10^{-2}$ & $5.4 \times 10^{-3}$ & $9.5 \times 10^{-3}$ & $9.8 \times 10^{-3}$ \\
80 & $6.3 \times 10^{-3}$ & $2.6 \times 10^{-3}$ & $2.0 \times 10^{-2}$ & $2.5 \times 10^{-3}$ & $5.8 \times 10^{-2}$ & $1.0 \times 10^{-2}$ & $2.0 \times 10^{-2}$ & $3.1 \times 10^{-2}$ \\
120 & $6.1 \times 10^{-3}$ & $7.4 \times 10^{-3}$ & $2.5 \times 10^{-2}$ & $4.7 \times 10^{-4}$ & $7.4 \times 10^{-2}$ & $1.2 \times 10^{-2}$ & $2.5 \times 10^{-2}$ & $6.1 \times 10^{-2}$ \\
160 & $4.7 \times 10^{-3}$ & $6.5 \times 10^{-3}$ & $3.0 \times 10^{-2}$ & $5.8 \times 10^{-3}$ & $8.2 \times 10^{-2}$ & $1.7 \times 10^{-2}$ & $2.1 \times 10^{-2}$ & $7.8 \times 10^{-2}$ \\
200 & $7.1 \times 10^{-3}$ & $2.6 \times 10^{-2}$ & $5.8 \times 10^{-2}$ & $6.8 \times 10^{-3}$ & $9.4 \times 10^{-2}$ & $2.3 \times 10^{-2}$ & $2.6 \times 10^{-2}$ & $6.5 \times 10^{-2}$ \\
\hline
\end{tabular}

A closer inspection of the variation of the values of conductivity with the temperature according to an Arrhenius plot (ln $\sigma$ vs 1000/T) is shown in Figure 7. In order to further study the proton conduction mechanism of the PA-doped composite membranes, the activation energy ( $E_{\text {act }}$ ) was calculated. From this plot, it is evident that the activation energy associated to the conductivity mechanism is not constant over the whole range of temperatures. The activation energy is much higher at lower temperatures than at the higher. In agreement with our experimental results, we have obtained the temperature dependence of the conductivity according to a Vogel-Fulcher-Tammann (VFT) equation given by:

$$
\log \sigma=\log \sigma_{\infty}-\frac{E_{\mathrm{act}}}{R\left(T-T_{0}\right)}
$$

where $\sigma$ is the proton conductivity in $\mathrm{S} \mathrm{cm}^{-1}, \sigma_{0}$ is the preexponential factor, $\mathrm{E}_{\text {act }}$ is the activation energy of the process underlying the dc-conductivity $\left(\sigma_{\mathrm{dc}}\right)$, and $R$ is the gas constant $\left(8.314 \mathrm{~J} \cdot \mathrm{mol}^{-1} \cdot \mathrm{K}^{-1}\right)$. Notice that $E_{\text {act }} / R$ is a fitting parameter related with the curvature of the plot identical to the VFT parameter with units of temperature in Kelvin, and $T_{0}$ is the Vogel temperature, considered as the one at which the relaxation time would diverge, and $\sigma_{\infty}$ is a pre-factor related with the limit conductivity at higher temperatures.

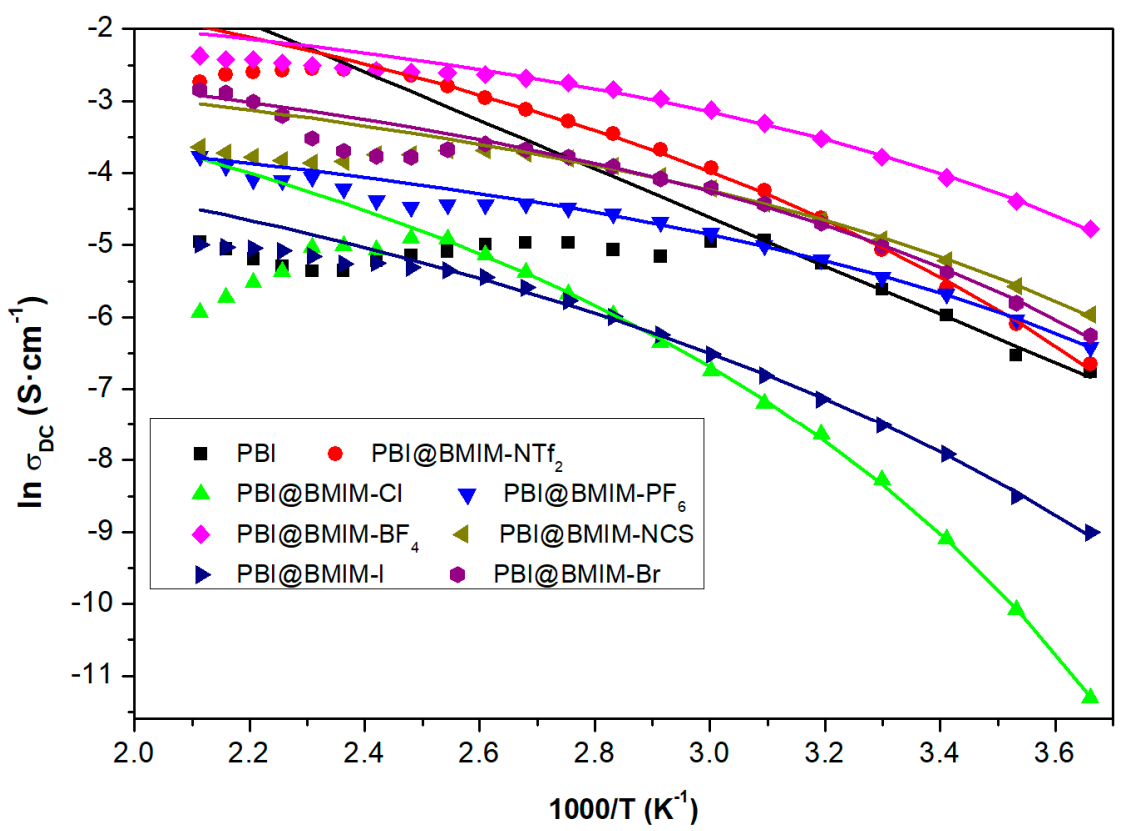

Figure 7. Representation of the $\ln$ of conductivity $\left(\sigma_{\mathrm{dc}}\right)$ as a function of the reciprocal of the temperature for phosphoric acid-doped PBI composite membranes containing $5 \mathrm{wt}$. \% of BMIM-X.

The corresponding values obtained for the VFT parameters, $\mathrm{T}_{0}$ and $\sigma_{\infty}$, are shown in Table 3. In order to study in detail the proton conduction mechanism of the PA-doped composite membranes, the activation energy $\left(\mathrm{E}_{\mathrm{act}}\right)$ was calculated. The calculated values for the activation energy for 
IL-containing PBI membranes decrease according to the following trend $[\mathrm{Cl}]^{-}>[\mathrm{I}]^{-}>\left[\mathrm{NTf}_{2}\right]^{-}>[\mathrm{Br}]^{-}$ $>[\mathrm{NCS}]^{-}>\left[\mathrm{BF}_{4}\right]^{-} \approx\left[\mathrm{PF}_{6}\right]^{-}$, and were in the range of $2.5-6.3 \mathrm{~kJ} \cdot \mathrm{mol}^{-1}$, which are lower compared to other reported values of PA-doped PBI membranes [69-71] and lower for that obtained for the pristine PBI membrane $\left(26.8 \mathrm{~kJ} \cdot \mathrm{mol}^{-1}\right)$.

Table 3. VFT fitting parameters for the PBI composite membranes under anhydrous conditions studied in this work.

\begin{tabular}{|c|c|c|c|}
\hline Membrane & $\operatorname{Ln} \sigma_{\infty}\left(\mathrm{S} \cdot \mathrm{cm}^{-1}\right)$ & $T_{0}(\mathrm{~K})$ & $E_{\text {act }}\left(\mathrm{kJ} \cdot \mathrm{mol}^{-1}\right)$ \\
\hline PBI@BMIM-Cl & -1.02 & 199 & 6.33 \\
\hline PBI@BMIM-Br & -1.61 & 195 & 3.04 \\
\hline PBI@BMIM-I & -2.19 & 172 & 5.80 \\
\hline PBI@BMIM-BF4 & -0.97 & 194 & 2.53 \\
\hline PBI@BMIM-PF6 & -2.72 & 192 & 2.51 \\
\hline PBI@BMIM-NCS & -1.81 & 190 & 2.91 \\
\hline PBI@BMIM-NTf 2 & 0.24 & 181 & 5.35 \\
\hline
\end{tabular}

As seen from the Arrhenius plot in Figure 7, the addition of 5\% BMIN-Cl and BMIN-I to the PBI matrix shows a decrease of conductivity in comparison with the pristine PBI [71]. However, the incorporation of the other ILs produces an important increase of conductivity when the membrane is doped with $15 \mathrm{M}$ phosphoric acid. This variation may be related with the coulomb energy of the cation-anion pair present in the ionic liquid, which is determined by the temperature dependence of the free ion concentration in the polymeric matrix. It is known that the conductivity of a polymer electrolyte can be described by the Einstein expression as $\sigma=n q \mu$, where $n$ is the free charge density, $\mathrm{q}$ is the charge of a monovalent ion, and $\mu$ its mobility [72]. Considering that $\mathrm{n}$ is temperature dependent, $\mathrm{n}(\mathrm{T})$, and knowing that the mobility of free ions is expected to be controlled by the segmental motion of the polymeric matrix of PBI, which in turn will depend on the temperature, $\mu(T)$. The real temperature dependence of conductivity will be under the influence of both dependences. Consequently, the expression shown in Equation (1) will be only an approximation to the real prediction of temperature dependency of the conductivity. From the fits, we find ionic conductivity to be in reasonable agreement with Equation (1), resulting in that the curvature of the fit in conductivity originates from VFT temperature dependence could be more strongly associate to the ionic mobility than charge density. From our results, we can see that at $120^{\circ} \mathrm{C}$, the conductivity varies between $4.7 \times 10^{-4}$ and $6.2 \times 10^{-2} \mathrm{~S} \cdot \mathrm{cm}^{-1}$ depending on the type of anion. These values are goods as a polymer electrolyte to be applied in fuel cells to work at moderate and high temperatures, at least in the range of $120-200{ }^{\circ} \mathrm{C}$.

\section{Conclusions}

In summary, this contribution presents a series of proton exchange membranes based on polybenzimidazole (PBI) enhanced using the low cost ionic liquids (ILs) derived from 1-butyl-3-methylimidazolium (BMIM) as conductive fillers in the polymeric matrix. The incorporation of ionic liquids as fillers in PBI membranes improves the mechanical properties of the composite membrane by an interaction between the polymer matrix and the IL. In this regard, conductivities up to $94 \mathrm{mS} \cdot \mathrm{cm}^{-1}$ have been obtained for the corresponding composite membrane containing BMIM-BF4 at $200{ }^{\circ} \mathrm{C}$ under anhydrous conditions. These results here presented show that a fine-tuning of polymer composite membranes can be achieved by the proper selection of the ionic liquid used in their preparation. This modular behavior facilitates the optimization process and opens the way for the future development of high-temperature electrolytes for further applications in different fields, in particular as electrochemical devices in energy-related areas.

Supplementary Materials: The following materials are available online at http://www.mdpi.com/2073-4360/11/ 4/732/s1, Table S1: Conductivity values obtained from the Bode diagram for all phosphoric acid doped PBI 
composite membranes containing 5 wt. \% of BMIM-X under anhydrous conditions; Figure S1: Bode diagram for phosphoric acid doped PBI@BMIM-Cl composite membrane under anhydrous conditions; Figure S2: Bode diagram for phosphoric acid doped PBI@BMIM-Br composite membrane under anhydrous conditions; Figure S3: Bode diagram for phosphoric acid doped PBI@BMIM-I composite membrane under anhydrous conditions; Figure S4: Bode diagram for phosphoric acid doped PBI@BMIM-BF ${ }_{4}$ composite membrane under anhydrous conditions; Figure S5: Bode diagram for phosphoric acid doped PBI@BMIM-PF 6 composite membrane under anhydrous conditions; Figure S6: Bode diagram for phosphoric acid doped PBI@BMIM-NCS composite membrane under anhydrous conditions.

Author Contributions: Conceptualization, V.C.; investigation, J.E.; TGA measurements, Ó.S.; EIS measurements A.G.-B.; mechanical behavior E.G.; writing-original draft preparation, J.E.; writing—review and editing, J.E., Á.M. and V.C.; supervision, V.C.; project administration, V.C.; funding acquisition, V.C.; J.E., Ó.S., Á.M., E.G. and V.C. contributed to the discussions. All the authors approved the final version of the manuscript.

Funding: The authors acknowledge the Spanish Ministerio de Economía y Competitividad (MINECO) for the financial support under the project ENE/2015-69203-R.

Acknowledgments: The authors acknowledge Santiago V. Luis from Universitat Jaume I for technical assistance with IR measurements.

Conflicts of Interest: The authors declare no conflict of interest.

\section{References}

1. Ye, Y.-S.; Rick, J.; Hwang, B.-J. Water soluble polymers as proton exchange membranes for fuel cells. Polymers 2012, 4, 913-963. [CrossRef]

2. Steele, B.C.H.; Heinzel, A. Materials for fuel-cell technologies. Nature 2001, 414, 345-352. [CrossRef]

3. Kreuer, K.-D. Proton conductivity: materials and applications. Chem. Mater. 1996, 8, 610-641. [CrossRef]

4. Bakangura, E.; Wu, L.; Ge, L.; Yang, Z.; Xu, T. Mixed matrix proton exchange membranes for fuel cells: State of the art and perspectives. Prog. Polym. Sci. 2016, 57, 103-152. [CrossRef]

5. Devanathan, R. Recent developments in proton exchange membranes for fuel cells. Energy Environ. Sci. 2008, 1, 101-119. [CrossRef]

6. Wang, Y.; Chen, K.S.; Mishler, J.; Cho, S.C.; Adroher, X.C. A review of polymer electrolyte membrane fuel cells: Technology, applications, and needs on fundamental research. Appl. Energy 2011, 88, 981-1007. [CrossRef]

7. Savage, J.; Tse, Y.-L.S.; Voth, G.A. Proton transport mechanism of perfluorosulfonic acid membranes. J. Phys. Chem. C 2014, 118, 17436-17445. [CrossRef]

8. Mauritz, K.A.; Moore, R.B. State of understanding of Nafion. Chem. Rev. 2004, 104, 4535-4586. [CrossRef] [PubMed]

9. Liu, L.; Chen, W.; Li, Y. An overview of the proton conductivity of Nafion membranes through a statistical analysis. J. Membr. Sci. 2016, 504, 1-9. [CrossRef]

10. Xia, R.; Zhou, H.; Wu, R.; Wu, W.-P. Nanoindentation Investigation of Temperature Effects on the Mechanical Properties of Nafion ${ }^{\circledR}$ 117. Polymers 2016, 8, 344. [CrossRef]

11. Kraytsberg, A.; Ein-Eli, Y. Review of advanced materials for proton exchange membrane fuel cells. Energy Fuels 2014, 28, 7303-7330. [CrossRef]

12. Hickner, M.A.; Ghassemi, H.; Kim, Y.S.; Einsla, B.R.; McGrath, J.E. Alternative polymer systems for proton exchange membranes (PEMs). Chem. Rev. 2004, 104, 4587-4612. [CrossRef] [PubMed]

13. Zhang, J.; Xie, Z.; Zhang, J.; Tang, Y.; Song, C.; Navessin, T.; Shi, Z.; Song, D.; Wang, H.; Wilkinson, D.P.; et al. High temperature PEM fuel cells. J. Power Sources 2006, 160, 872-891. [CrossRef]

14. Choi, S.-W.; Park, J.O.; Pak, C.; Choi, K.H.; Lee, J.-C.; Chang, H. Design and synthesis of cross-linked copolymer membranes based on poly(benzoxazine) and polybenzimidazole and their application to an electrolyte membrane for a high-temperature PEM fuel cell. Polymers 2013, 5, 77-111. [CrossRef]

15. Vinothkannan, M.; Kim, A.R.; Gnana Kumar, G.; Yoon, J.M.; Yoo, D.J. Toward improved mechanical strength, oxidative stability and proton conductivity of an aligned quadratic hybrid (SPEEK/FPAPB/ $\left./ \mathrm{Fe}_{3} \mathrm{O}_{4}-\mathrm{FGO}\right)$ membrane for application in high temperature and low humidity fuel cells. RSC Adv. 2017, 7, 39034-39048. [CrossRef]

16. Kim, A.R.; Yoo, D.J. A comparative study on physiochemical, thermomechanical, and electrochemical properties of sulfonated poly(ether ether ketone) block copolymer membranes with and without $\mathrm{Fe}_{3} \mathrm{O}_{4}$ nanoparticles. Polymers 2019, 11, 536. [CrossRef] [PubMed] 
17. Uregen, N.; Pehlivanoglu, K.; Ozdemir, Y.; Devrim, Y. Development of polybenzimidazole/graphene oxide composite membranes for high temperature PEM fuel cells. Int. J. Hydrogen Energy 2017, 42, 2636-2647. [CrossRef]

18. Wieser, C. Novel polymer electrolyte membranes for automotive applications—requirements and benefits. Fuel Cells 2004, 4, 245-250. [CrossRef]

19. Rasheed, R.K.A.; Liao, Q.; Zhang, C.; Chan, S.H. A review on modelling of high temperature proton exchange membrane fuel cells (HT-PEIVIFCs). Int. J. Hydrogen Energy 2017, 42, 3142-3165.

20. Araya, S.S.; Zhou, F.; Liso, V.; Sahlin, S.L.; Vang, J.R.; Thomas, S.; Gao, X.; Jeppesen, C.; Kaer, S.K. A comprehensive review of PBI-based high temperature PEM fuel cells. Int. J. Hydrogen Energy 2016, 41, 21310-21344. [CrossRef]

21. Li, J.; Li, X.; Zhao, Y.; Lu, W.; Shao, Z.; Yi, B. High-temperature proton-exchange-membrane fuel cells using an ether-containing polybenzimidazole membrane as electrolyte. ChemSusChem 2012, 5, 896-900. [CrossRef]

22. Ghosh, S.; Maity, S.; Jana, T. Polybenzimidazole/silica nanocomposites: Organic-inorganic hybrid membranes for PEM fuel cell. J. Mater. Chem. 2011, 21, 14897-14906. [CrossRef]

23. Singha, S.; Jana, T. Influence of interfacial interactions on the properties of polybenzimidazole/clay nanocomposite electrolyte membrane. Polymer 2016, 98, 20-31. [CrossRef]

24. Fuentes, I.; Andrio, A.; Garcia-Bernabé, A.; Escorihuela, J.; Viñas, C.; Teixidor, F.; Compañ, V. Structural and dielectric properties of cobaltacarborane composite polybenzimidazole membranes as solid polymer electrolytes at high temperatura. Phys. Chem. Chem. Phys. 2018, 20, 10173-10184. [CrossRef]

25. Ozdemir, Y.; Uregen, N.; Devrim, Y. Polybenzimidazole based nanocomposite membranes with enhanced proton conductivity for high temperature PEM fuel cells. Int. J. Hydrogen Energy 2017, 42, 2648-2657. [CrossRef]

26. Xu, C.X.; Wu, X.; Wang, X.; Mamlouk, M.; Scott, K. Composite membranes of polybenzimidazole and caesium-salts-of-heteropolyacids for intermediate temperature fuel cells. J. Mater. Chem. 2011, 21, 6014-6019. [CrossRef]

27. Escorihuela, J.; Narducci, R.; Compañ, V.; Costantino, F. Proton conductivity of composite polyelectrolyte membranes with metal-organic frameworks for fuel cell applications. Adv. Mater. Interfaces 2019, 6, 1801146. [CrossRef]

28. Barjola, A.; Escorihuela, J.; Andrio, A.; Giménez, E.; Compañ, V. Enhanced conductivity of composite membranes based on sulfonated poly(ether ether ketone) (SPEEK) with zeolitic imidazolate frameworks (ZIFs). Nanomaterials 2018, 8, 1042. [CrossRef]

29. Vinothkannan, M.; Kim, A.R.; Gnana Kumar, G.; Yoo, D.J. Sulfonated graphene oxide/Nafion composite membranes for high temperature and low humidity proton exchange membrane fuel cells. RSC Adv. 2018, 8, 7494-7508. [CrossRef]

30. Cheng, T.; Zhang, X.; Ma, Y.; Huang, Y.; Xiaobo Liu, X. Constructing continuous proton-conducting highways within sulfonated poly(arylene ether nitrile) composite membrane by incorporating amino-sulfo-bifunctionalized GO. Polymers 2018, 10, 1005. [CrossRef] [PubMed]

31. Liu, F.X.; Wang, S.; Li, J.S.; Tian, X.; Wang, X.; Chen, H.; Wang, Z. Polybenzimidazole/ionic-liquid-functional silica composite membranes with improved proton conductivity for high temperature proton exchange membrane fuel cells. J. Membr. Sci. 2017, 541, 492-499. [CrossRef]

32. Altava, B.; Compañ, V.; Andrio, A.; Del Castillo, L.F.; Mollá, S.; Burguete, M.I.; García-Verdugo, E.; Luis, S.V. Conductive films based on composite polymers containing ionic liquids absorbed on crosslinked polymeric ionic-like liquids (SILLPs). Polymer 2015, 72, 69-81. [CrossRef]

33. Earle, M.J.; Seddon, K.R. Ionic liquids. Green solvents for the future. Pure Appl. Chem. 2000, 72, 1391-1398. [CrossRef]

34. Plechkova, N.V.; Seddon, K.R. Applications of ionic liquids in the chemical industry. Chem. Soc. Rev. 2008, 37, 123-150. [CrossRef]

35. Ye, Y.-S.; Ricka, J.; Hwang, B.-J. Ionic liquid polymer electrolytes. J. Mater. Chem. A 2013, 1, $2719-2743$. [CrossRef]

36. Armand, M.; Endres, F.; MacFarlane, D.R.; Ohno, H.; Scrosati, B. Ionic-liquid materials for the electrochemical challenges of the future. Nat. Mater. 2009, 8, 621-629. [CrossRef]

37. Chen, D.; Ying, W.; Guo, Y.; Ying, Y.; Peng, X. Enhanced Gas Separation through Nanoconfined Ionic Liquid in Laminated MoS2 Membrane. ACS Appl. Mater. Interfaces 2017, 9, 44251-44257. [CrossRef] [PubMed] 
38. Marrucho, I.M.; Branco, L.C.; Rebelo LP, N. Ionic Liquids in Pharmaceutical Applications. Annu. Rev. Chem. Biomol. Eng. 2014, 5, 527-546. [CrossRef] [PubMed]

39. Egorova, K.S.; Gordeev, E.G.; Ananikov, V.P. Biological activity of ionic liquids and their application in pharmaceutics and medicine. Chem. Rev. 2017, 117, 7132-7189. [CrossRef] [PubMed]

40. González-Mendoza, L.; Altava, B.; Burguete, M.I.; Escorihuela, J.; Hernando, E.; Luis, S.V.; Quesada, R.; Vicent, C. Bis(imidazolium) salts derived from amino acids as receptors and transport agents for chloride anions. RSC Advances 2015, 5, 34415-34423. [CrossRef]

41. Dai, C.; Zhang, J.; Huang, C.; Lei, Z. Ionic liquids in selective oxidation: catalysts and solvents. Chem. Rev. 2017, 117, 6929-6983. [CrossRef]

42. Liu, Y.; Wang, M.; Li, J.; Li, Z.; He, P.; Liu, H.; Li, J. Highly active horseradish peroxidase immobilized in 1-butyl-3-methylimidazolium tetrafluoroborate room-temperature ionic liquid based sol-gel host materials. Chem. Commun. 2005, 1778-1780. [CrossRef]

43. González, L.; Escorihuela, J.; Altava, B.; Burguete, M.I.; Luis, S.V. Chiral room temperature ionic liquids as enantioselective promoters for the asymmetric aldol reaction. Eur. J. Org. Chem. 2014, 5356-5363. [CrossRef]

44. Watanabe, M.; Thomas, M.L.; Zhang, S.; Ueno, K.; Yasuda, T.; Dokko, K. Application of ionic liquids to energy storage and conversion materials and devices. Chem. Rev. 2017, 117, 7190-7239. [CrossRef]

45. Díaz, M.; Ortiz, A.; Ortiz, I. Progress in the use of ionic liquids as electrolyte membranes in fuel cells. J. Membr. Sci. 2017, 469, 379-396. [CrossRef]

46. MacFarlane, D.R.; Tachikawa, N.; Forsyth, M.; Pringle, J.M.; Howlett, P.C.; Elliott, G.D.; Davis, J.H., Jr.; Watanabe, M.; Simon, P.; Angell, C.A. Energy applications of ionic liquids. Energy Environ. Sci. 2014, 7, 232-250. [CrossRef]

47. Mecerreyes, D. Polymeric ionic liquids: broadening the properties and applications of polyelectrolytes. Prog. Polym. Sci. 2011, 36, 1629-1648. [CrossRef]

48. Sun, P.; Li, Z.; Jin, L.; Yang, Y.; Wang, S.; Yin, X.; Wang, Y. Pre-oxidized acrylic fiber reinforced ferric sulfophenyl phosphate-doped polybenzimidazole-based high-temperature proton exchange membrane. Macromol. Mater. Eng. 2017, 302, 1600468. [CrossRef]

49. Hanke, K.; Kaufmann, M.; Schwaab, G.; Havenith, M.; Wolke, C.T.; Gorlova, O.; Johnson, M.A.; Prasad Kar, B.; Sander, W.; Sanchez-Garcia, E. Understanding the ionic liquid [NC4111][NTf2] from individual building blocks: an IR-spectroscopic study. Phys. Chem. Chem. Phys. 2015, 17, 8518-8529. [CrossRef]

50. Wang, X.; Wang, S.; Liu, C.; Li, J.; Liu, F.; Tian, X.; Chen, H.; Mao, T.; Xu, J.; Wang, Z. Cage-like cross-linked membranes with excellent ionic liquid retention and elevated proton conductivity for HT-PEMFCs. Electrochimica Acta 2018, 283, 691-698. [CrossRef]

51. Mack, F.; Aniol, K.; Ellwein, C.; Kerres, J.; Zeis, R. Novel phosphoric acid-doped PBI-blends as membranes for high-temperature PEM fuel cells. J. Mater. Chem. A 2015, 3, 10864-10874. [CrossRef]

52. Cao, Y.; Tiancheng Mu, T. Comprehensive investigation on the thermal stability of 66 ionic liquids by thermogravimetric analysis. Ind. Eng. Chem. Res. 2014, 53, 8651-8664. [CrossRef]

53. Wang, S.; Zhao, C.J.; Ma, W.J.; Zhang, G.; Liu, Z.G.; Ni, J.; Li, M.Y.; Zhang, N.; Na, H. Preparation and properties of epoxy-cross-linked porous polybenzimidazole for high temperature proton exchange membrane fuel cells. J. Membr. Sci. 2012, 411-412, 54-63. [CrossRef]

54. Chuang, S.W.; Hsu, S.L.C. Synthesis and properties of a new fluorine-containing polybenzimidazole for high-temperature fuel-cell applications. J. Polym. Sci. A 2006, 44, 4508-4513. [CrossRef]

55. Wang, J.T.-W.; Hsu, S.L.-C. Enhanced high-temperature polymer electrolyte membrane for fuel cells based on polybenzimidazole and ionic liquids. Electrochim. Acta 2011, 56, 2842-2846. [CrossRef]

56. Han, M.; Zhang, G.; Liu, Z.; Wang, S.; Li, M.; Zhu, J.; Li, H.; Zhang, Y.; Lew, C.M.; Na, H. Cross-linked polybenzimidazole with enhanced stability for high temperature proton exchange membrane fuel cells. J. Mater. Chem. 2011, 21, 2187-2193. [CrossRef]

57. Wang, S.; Zhao, C.; Ma, W.; Zhang, N.; Liu, Z.; Zhang, G.; Na, H. Macromolecular cross-linked polybenzimidazole based on bromomethylated poly (aryl ether ketone) with enhanced stability for high temperature fuel cell applications. J. Power Sources 2013, 243, 102-109. [CrossRef]

58. Liu, F.; Wang, S.; Chen, H.; Li, J.; Tian, X.; Wang, X.; Mao, T.; Xu, J.; Wang, Z. Cross-linkable polymeric ionic liquid improve phosphoric acid retention and long-term conductivity stability in polybenzimidazole based PEMs. ACS Sustainable Chem. Eng. 2018, 6, 16352-16362. [CrossRef] 
59. Wang, S.; Zhao, C.; Ma, W.; Zhang, N.; Zhang, Y.; Zhang, G.; Liu, Z.; Na, H. Silane-cross-linked polybenzimidazole with improved conductivity for high temperature proton exchange membrane fuel cells. J. Mater. Chem. A 2013, 1, 621-629. [CrossRef]

60. Zhang, W.; Chen, S.; Chen, D.; Ye, Z. Sulfonated binaphthyl-containing poly(arylene ether ketone)s with rigid backbone and excellent film-forming capability for proton exchange membranes. Polymers 2018, 10, 1287. [CrossRef] [PubMed]

61. Rewar, A.S.; Chaudhari, H.D.; Illathvalappil, R.; Sreekumar, K.; Kharul, U.K. New approach of blending polymeric ionic liquid with polybenzimidazole (PBI) for enhancing physical and electrochemical properties. J. Mater. Chem. A 2014, 2, 14449-14458. [CrossRef]

62. Li, Q.; Jensen, J.O.; Savinell, R.F.; Bjerruma, N.J. High temperature proton exchange membranes based on polybenzimidazoles for fuel cells. Prog. Polym. Sci. 2009, 34, 449-477. [CrossRef]

63. Randviir, E.P.; Banks, C.E. Electrochemical impedance spectroscopy: an overview of bioanalytical applications. Anal. Methods 2013, 5, 1098-1115. [CrossRef]

64. Sacco, A. Electrochemical impedance spectroscopy: Fundamentals and application in dye-sensitized solar cells. Renewable Sustainable Energy Rev. 2017, 79, 814-829. [CrossRef]

65. Bode, H.W. Network Analysis and Feedback Amplifier Design; Van Nostrand: Princeton, NJ, USA, 1945.

66. Reyes-Rodriguez, J.L.; Escorihuela, J.; García-Bernabé, A.; Giménez, E.; Solorza-Feria, O.; Compañ, V. Proton conducting electrospun sulfonated polyether ether ketone graphene oxide composite membranes. RSC Adv. 2017, 7, 53481-53491. [CrossRef]

67. Ghatee, M.H.; Zolghadr, A.R. Local depolarization in hydrophobic and hydrophilic ionic liquids/water mixtures: Car-Parrinello and classical molecular dynamics simulation. J. Phys. Chem. C 2013, 117, 2066-2077. [CrossRef]

68. Chen, B.-K.; Wu, T.-Y.; Wong, J.-M.; Chang, Y.-M.; Lee, H.-F.; Huang, W.-Y.; Chen, A.F. Highly sulfonated diamine synthesized polyimides and protic ionic liquid composite membranes improve PEM conductivity. Polymers 2015, 7, 1046-1065. [CrossRef]

69. Pu, H.T.; Wang, L.; Pan, H.Y.; Wan, D.C. Synthesis and characterization of fluorine-containing polybenzimidazole for proton conducting membranes in fuel cell. J. Polym. Sci. Part A 2010, 48, 2115-2122. [CrossRef]

70. Sun, P.; Li, Z.; Wang, S.; Yin, X. Performance enhancement of polybenzimidazole based high temperature proton exchange membranes with multifunctional crosslinker and highly sulfonated polyaniline. J. Membr. Sci. 2018, 549, 660-669. [CrossRef]

71. Escorihuela, J.; Sahuquillo, O.; García-Bernabé, A.; Giménez, E.; Compañ, V. Phosphoric acid doped polybenzimidazole (PBI)/zeolitic imidazolate framework composite membranes with significantly enhanced proton conductivity under low humidity conditions. Nanomaterials 2018, 8, 775. [CrossRef] [PubMed]

72. Barker, R.E., Jr. Mobility and conductivity of ions in and into polymeric solids. Pure Appl. Chem. 1976, 46, 157-170. [CrossRef]

(C) 2019 by the authors. Licensee MDPI, Basel, Switzerland. This article is an open access article distributed under the terms and conditions of the Creative Commons Attribution (CC BY) license (http://creativecommons.org/licenses/by/4.0/). 